\title{
LITERARY KALEVALA-METRE AND HYBRID POETICS IN THE SIXTEENTH AND SEVENTEENTH CENTURY FINLAND
}

\author{
Kati Kallio
}

\begin{abstract}
This article examines the blurred boundaries between different oral and literary poetics in early modern Finland. Both the first written examples of traditional Finnic oral poetry (in so-called Kalevala-metre with no rhymes or stanza structures) and the first rhymed and stanzaic poems originate from this very same period, often in various hybrid forms. Ambiguity and the hybrid character of poems means the contemporary audiences may have interpreted individual poems as relating to several poetic traditions.

The material demonstrates that the elites had knowledge of oral poetics that they both avoided and applied in various ways. In Lutheran hymns, the features of traditional oral poetry were first avoided, but, from the 1580 s onwards, alliteration and some other features were incorporated into rhymed, iambic stanzas. At the same time, the clergymen and scholars also created a rhymed, heavily alliterated and trochaic genre of literary poems, which was apparently conceived as a version of the oral Finnish poetic form. Later scholars have often interpreted this learned, literary form as a misunderstanding of traditional oral poetics. In this article, it is understood as an intentional, hybrid form of rhymed couplets and Kalevala-metre. The various hybrid uses indicate that - contrary to the later scholarly views - the early modern writers did not conceive the old oral form as a conclusively pagan metre that should be strictly avoided.
\end{abstract}

Keywords: ethnopoetics, Finnic oral poetry, hybrid poetics, Kalevala-metre, literary history, Lutheran hymns, rhymed couplets

The first texts in Finnish derive from the sixteenth and seventeenth centuries. Apart from some oral-derived charms and mocking songs in the court registers, the poems in the earliest Finnish sources were mostly written by the clerical, literary elite, who created the new genres of Lutheran hymns and literary poetry. The hybrid and oral-literary character of these earliest sources has resulted in a rather small interest in these materials both among the folklorists and literary scholars. Yet, the contemporary discussions on the interfaces between oral and literary traditions, ethnopoetics, and song metrics have created some new possibilities for interpreting early modern vernacular poetics. 
Up to 1809, most of today's Finland formed the eastern part of the Swedish Kingdom. The Reformation in Sweden (1527-) marked a counterpoint in Finnish poetry. Along with the Reformation, the vernacular languages were taken into literary and liturgical use, rhymed Lutheran hymns were created, and the congregation was gradually taught to sing in the services. Latin remained the most important scholarly and ecclesiastical language, and Swedish was used in administration. It has been estimated that the most important writers of Finnish hymns, poems, and liturgical songs spoke Finnish as their mother tongue or as a very strong secondary language (Häkkinen 2005; 2015: 32-33; Savijärvi 1995). Thus, the situation is rather different from the Reformation in the Baltic countries, where native speakers of German created most of the vernacular hymns and liturgical texts (Ross 2013, 2015; Grudule 2016).

It has been a common interpretation that the new Lutheran Church wanted to efface the old pagan oral idiom, the so-called runo-songs in alliterative Kalevala-metre, ${ }^{1}$ and slowly succeeded in this especially in western Finland (Kurvinen 1929: 14-17, 256-312; Sarajas 1956: 14-17; Siikala 2012: 28, 54-55, 97-98). It is true that the clergymen of the seventeenth century strictly condemned idolatry, sorcery, obscene songs, and ungodly behaviour (Sarajas 1956: 41-42, 69; Lehtonen 2016), and that the Finnish vernacular charms and mythological songs were often performed in Kalevala-metre (see, e.g., Siikala 2002). It is also true that no Lutheran hymns were written in the unrhymed style of traditional oral poetry. Yet, already Mikael Agricola, the leading figure of the Finnish Reformation and later the bishop of Åbo, printed one proverb and another short poem with oral-like stylistics in the first Finnish prayer book in 1543. Later, at the height of the Lutheran Orthodoxy, alliteration - the most visible or audible feature of traditional runo-songs - was incorporated into Lutheran hymns and literary poems, and, towards the end of the seventeenth century, the Kalevalametre with alliteration, parallelism, poetic formulas, and syntax in oral style was used in literary poems by some clergymen. The most evident proof of the appropriation of the oral poetic form is the Lutheran Messiah of 2265 verses written in beautiful oral-like, unrhymed Kalevala-metre, published by a Lutheran priest Matthias Salamnius in 1690 (Kallio 2015b, 2016; Kuusi 1998).

From the nineteenth century onwards, the versatile character of the early modern literary Finnish poetics with hybrid forms, incomplete rhymes, and varying amounts of syllables tended to be interpreted as poorly developed and inadequate (Krohn 1862; Melander 1928; Sarajas 1956). Yet, taking an ethnopoetic view (Hymes 1981; Tedlock 1983), it seems evident that these features related to the vernacular aesthetics and oral-literary character of these texts. For the historical audiences, versatility and variation were appropriate features 
of vernacular poetry (Laitinen 2005). We only have little and mostly hypothetical information of the variety of oral poetics and practices that surrounded the Finnish early modern literary works, but it is evident that the learned men created their vernacular songs and poems in relation to different poetic registers they knew in different languages, both in oral and literary forms, including Finnish oral poetics.

This article focuses on the uses of runo-song stylistics and Kalevala-metre in literary contexts and examines the blurred boundaries between different oral and literary poetics in early modern Finland. The analysis is based on previous research on the uses of Kalevala-metre in literary poetry (Häkkinen 2013; Kallio 2015b; Leino 2002 [1975]; Melander 1928; Sarajas 1956) and on the early hymns and chapbook songs (Kurvinen 1929, 1941; Laitinen 2005; Niinimäki 2007; see also Bastman 2014; Kallio 2016). The early modern poetic material includes the first Finnish hymnals and liturgical songs; some rhymed prefaces, a chronicle, and some other literary works; a few proverbs; literary congratulations, dedications, and condolences; and some oral charms and mocking songs in the court registers. Of these, only some proverbs, charms, mocking songs, and some late seventeenth-century literary works confine to all the constraints of traditional oral poetic system. Herein I use the term Kalevala-metre for the traditional Finnish tetrametre, and the term runo-song for the larger poetic phenomena related to this metre, but exhibiting some more variation. Hymn is used for both Lutheran and Catholic rhymed songs. The article is based on general reading of the corpus, mainly on the basis of published or digitised sources, and on more detailed analysis of some examples.

\section{ORAL-LITERARY POETIC REGISTERS}

Literary and oral cultures used to be seen as two separate enclaves. Scholars have provided useful insights of the typical characteristics of both categories (Ong 1982), but it was only the perspectives on the interactions of literary and oral traditions, and on the large scale of different oralities, literacies, and hybrid forms between these two, which opened up the discussion of the actual workings of oral and literary processes (Finnegan 1977; Foley 1995, 2002; see also Burke 2009 [1978]; DuBois 2006; Hansson 2000; Kuismin \& Driscoll 2013; Laitinen \& Mikkola 2013; Ramsten \& Strand \& Ternhag 2015; Tarkka 2013: 46-52, 80-84; on the concept of hybrid, see Kapchan \& Turner Strong 1999). Literary traditions may be connected with or use features of oral traditions, and literary and oral traditions may interact in numerous ways. Literary and 
oral spheres may relate, in various combinations, to processes of composing, recording, preserving, disseminating or using a poem. With hymns in particular, the oral character of even the most literary works is evident: these poems were affected by melodic structures and made for oral use (Laitinen 2003: 183, 207).

Although examples of rather classical forms of iambic tetrametre, regular verse structure, and complete rhymes are occasionally present in the early modern Finnish sources, most of the poems do not confine to these constraints. Thus, from the nineteenth century onwards, these poems were understood as undeveloped and clumsy. Since the 1970s, the ethnopoetic movement has reclaimed the value and meaning of vernacular and non-Western poetics, mostly based on Native American traditions. In this view, the linguistic and poetic structures should be analysed on the basis of the poetic cultures and practices themselves, not by valuing them on the basis of researchers' own cultural backgrounds and ideals. Both Dennis Tedlock (1983) and Dell Hymes (1981) have emphasised the meaning of performance and linguistic structures, such as intonations, exclamations, and breathing pauses, in creating culturally meaningful poetic patterns. Frog $(2010,2014)$ has discussed the problems that our own existing patterns of understanding poetics and metrics pose when we are confronted with past poetic traditions, which may be built on other principles.

In ethnomusicological research, Urve Lippus (1995) and Jarkko Niemi (1998) have analysed the structures of oral unaccompanied songs as an interaction of linguistic and musical levels (see also Niemi \& Jouste 2002; Oras 2010; Särg 2001, 2005). The relationships of metrics, music, and performance may take different forms. In many cases the knowledge of a performance tradition does not change the view on metrical structures (Kiparsky 2006). Yet, depending on the local singing culture, genre, and singer, the musical variation and verse structures are sometimes connected in intricate ways. In traditional Finnic oral poetry, some local traditions used additional or omitted syllables, various patterns of repetition and refrains, while most typically the verses were performed as such. The poetic lines had a rather strict relation to the typical short melodies of one or two verses in runo-songs, and two or four verses in rhymed songs (see, e.g., Lippus 1995; Laitinen 2006). Nevertheless, when analysing rhymed folk songs, Heikki Laitinen (2003: 209; see also Ekgren 2009; Niemi 1998) has remarked that the performed forms and the relationship of musical and linguistic structures are sometimes essential in defining and understanding the oral poetic metre.

The uttermost objective of this article lies in the ways the poetic forms have been understood and used in historical speech communities. Direct evaluations and descriptions of poetic styles are rare and vague until the learned poetics 
of the late eighteenth century. The main way to address the categorisations and valuations of the historical users of poetic forms is to analyse the ways in which they have used and combined different poetic features, contents, themes, performance contexts, writing practices, and genre labels. The basis for the further interpretation of the uses of poetic features lies in the views of linguistic registers as situational styles of communication, based on shared conventions within a speech community. The members of speech communities tend to associate linguistic registers (such as poetic forms) with some typical contents, ideologies, and contexts. By analysing how particular forms of language and performance have been used and evaluated, it is possible to access some shared meanings, identities, and beliefs associated with and carried by different poetic features. Yet, as Asif Agha notes, these associations tend not to be uniform or free from conflict even within a small speech community, and they may change over time (Agha 2004: 24; 2007; see also Kallio 2015a).

\section{POETIC LANGUAGES IN EARLY MODERN FINLAND}

On a very rough level, there are two common metrical systems in Finnish: Kalevala-metric (based on the stress and length of syllables) and accentual (based on the stress only). Typically, a poem in Kalevala-metre makes use of alliteration and parallelism, while accentual metres are combined with rhyme and stanza structures (Leino 1986). ${ }^{2}$ Yet, these systems exhibit a large scale of different metrical forms, poetic styles, genres, and performance practices, and they also appear in various hybrid forms. The large scale is most evident in rhymed songs. Already the first Finnish hymnal from 1583 represents a variety of verse forms with different patterns of stanza and rhyme (Finno 1988; Kurvinen 1929). Heikki Laitinen (2005: 205-312; see also Laurila 1956) shows that the later Finnish rhymed folk songs contain a large variety of verse and stanza forms, albeit the rhymed couplet called rekilaulu (not to be confused with the Estonian regilaul) is the most common one in the nineteenth- and twentieth-century sources. Pirjo-Liisa Niinimäki (2007) has shown the metrical variation and the most common poetic patterns in chapbook songs, and Anneli Asplund (1997; see also 1994) discussed the poetic and metrical variation of rhymed folk songs and ballads.

The early hymns and later folk songs alike demonstrate both rather loose and stricter metrics: already in the first hymnal, some songs were written with a rather strict number of syllables or patterns of stress, while in many songs these do vary to a degree that it is difficult to define the poem trochaic or iambic 
without comparing it to the original version in another language (Kallio 2016; Laitinen 2005). The unstable character of the early literary language poses another interpretive problem, as it is not always evident how some word might have been pronounced or divided into syllables. In addition, Kaisa Häkkinen (2005: 28) suggests that it was common for readers to read (or sing) the texts according to their own dialects. In Finland, this means a rather big variation in the word and verse lengths, as the words are significantly shorter in western dialects, and even more shortened in some poetic texts.

In Finnish folk and literary traditions alike, the rhymed, stanzaic poems are usually based on the alternation of stressed and unstressed syllables. Contrary to Kalevala-metre, the length of the stressed syllables is not observed. In Finnic languages the number of one-syllable words in use is rather small. Along with the fact that the first syllable of the word is always stressed, this poses some problems in creating iambic patterns, and makes iambic inversion a common strategy. Alliteration and parallelism may be occasionally used, but they have not been characteristic to the stanzaic, rhymed poems (Asplund 1997; Laitinen 2003: 205-312; Leino 1986). Typical of oral metres and some early literary poems alike is that the pattern and number of first syllables of the line may vary even within one song. This means that the distinction between iambic and trochaic metres is somewhat blurred and sometimes rather irrelevant (Laitinen forthcoming).

The rich variation of poetics in the early modern Finnish materials indicates that influences were adapted and combined from various genres and directions. Evidently, the early modern Finnish clergymen were familiar with various medieval Latin poetics and singing styles (Hornby 2009; Page 2010). Latin was still used after the Reformation as an ecclesiastical and scholarly language, and many medieval songs - both measured and unmeasured - were translated into vernacular Lutheran songs (Hannikainen \& Tuppurainen 2016). Most educated clergymen were familiar with both the classical Latin and Greek poetics and the oral and emerging literary vernacular poetics in several languages (Kurvinen 1929, 1941; Melander 1928). This means the early modern Finnish poets had models of very classical strict metrics, looser vernacular literary adaptations, and oral metrics in different languages. In Scandinavian and German late medieval and early modern metrics, it was common to have a varying number of syllables in poetic positions, accept some variation in patterns of stress, shorten the words according to poetic needs, and use rhymes that a modern reader would doom incomplete (Widoff 2013; Lilja 2006). On a large scale, stricter constraints were not fully applied to northern vernacular literary poetics until the influential German book on poetics by Martin Opitz 
in 1624 (Gasparov 1996: 194-197; Gillespie 1971; Opitz 2016). The first two editions of the Finnish hymnal $(1583,1605)$ were composed before these poetic changes, and these hymns were used up to the nineteenth century along with the more regular, later ones. Also, in Finnish oral rhymed songs these early modern poetic features persisted up to the twentieth century, along with stricter poetics (Asplund 1994, 1997; Laitinen 2003; Laurila 1956; Niinimäki 2007).

Kalevala-metre refers to oral Finnic trochaic tetrametre. In the strictest form of the metre, most common in Russian Karelia and eastern Finland, the first foot may contain 2-4 syllables, the others 2 syllables each. In Finnic languages the first syllable of a word or a part of a compound word is always stressed, although some one-syllable words may, depending on the context, be non-stressed. Apart from the first foot of Kalevala-metric verse, the long stressed syllables should be placed at the rises of the metre and the stressed short syllables at the falls, while the placing of unstressed syllables is free. The verses with short stressed syllables at the falls are called 'broken verses', and they usually constitute about half of the verses in Finnish and Karelian oral poems. Verses without short stressed syllables in falls are called 'normal verses' or 'normal trochee'. In traditional use, the poems in Kalevala-metre do not make use of stanzas or rhymes. Alliteration and parallelism are frequent, but not structural or obligatory in every verse (Leino 1986, 1994; Sarv 2008, 2011).

Yet, in the practices of local oral cultures, the verse structures were more complex (Lauerma 2004; Sarv 2008, 2011). In Russian and Finnish Karelia, the strictest, regular form of the metre, described above, was common, but for example in certain singing styles in Ladoga Karelia, the verses were sometimes expanded into lines of 12 syllables (e.g. SKS KRA), and, particularly in Ingria, the last syllable(s) of the line were not always sung (Kallio 2013: 136-177). In spoken and dictated forms of poems, the words were often closer to local dialect and, correspondingly, the lines shorter than in classical metre, whereas in songs the words and lines were typically longer and linguistic forms more archaic (Saarinen 1988: 198-199; Lauerma 2004: 24). Especially in proverbs, the scale of variation was large (Leino 1970). In songs, the shortened words of dialects were sometimes augmented with additional syllables, or syllables were lengthened to fill several poetic positions (Lauerma 2004: 24-65). Occasionally, the division of word into syllables varied according to metrical needs (Leino 1986: 71-75). Heikki Laitinen (2006: 38; see also Leino 2002 [1975]) has estimated that the acceptance of a short stressed syllable on the rise of a poetic foot might be a rather old phenomenon in the oral runo-song poetics of western Finland, although it is not common in the strictest Kalevala-metre. Mari Sarv (2011) has related similar phenomena in western and southern Estonia to the 
changes in language prosody, possibly as a result of old linguistic interaction with the Baltic and Scandinavian languages, which would be a relevant factor also in western Finland.

What further complicates the interpretations is that any detailed picture of the variation of oral poetic forms, genres, and performance practices in early modern Finland is beyond reach. It has been estimated that rhymed patterns started to be used in Finnish songs along the coastal line around the Reformation (Leino 1994: 56-57). Yet, theoretically, it would have been possible that some kind of experiments had been made much earlier. When the Christian faith was gradually taken into practice in Finland around the beginning of the second millennium, there were already rhymed Latin hymns in use, and in western Finland, both Swedish and German rhymed vernacular songs were plausibly heard through the Late Middle Ages (Häkkinen 2012: 23; see also Kallio 2015b). The scale of variation of runo-song poetics in early modern western Finland is beyond reach, although it is reasonable to assume that Kalevalametre (with local variations) was the dominant oral metre. In about 50 texts of seventeenth-century charms, regular oral-like Kalevala-metre dominates, while some occasional texts are more prose-like. Recorded proverbs and riddles mostly relate to Kalevala-metre, with many shortened and prose-like forms typical of spoken parts of the tradition. The five known seventeenth-century mocking songs in the court records represent both Kalevala-metric, rhymed, and hybrid styles, but Kalevala-metre proper is used only in the songs from central and eastern Finland. This indicates that, in western areas, most improvisational, contemporary oral poems were already applying accentual, rhymed metres. On the other hand, there are fine examples of rather regular Kalevala-metre from the nineteenth-century western Finland (Kallio et al. 2017; see also Asplund 2006; Kuusi 1954). The early modern oral poetic system seems to have been characterised by a variety of versatile metres.

\section{LUTHERAN HYMNS AND ALLITERATION}

The first sixteenth-century Finnish hymn makers avoided the explicit features of traditional oral runo-songs. Most evidently, this is shown by the use of rhyme and the rather stable avoidance of alliteration, explicit already in the few measured hymns of the first Finnish prayer book (1544) by Mikael Agricola. Jacobus Finno, the author of the first Finnish Lutheran hymnal (1583), said he wanted to write hymns "with rhyme, as is done in other Christian regions". Most of his hymns are translations or modifications of iambic Latin, German, 
and Swedish hymns. Although most of the Finnish hymns were written with rather loose constraints, they seem to be made to fit to particular melodies. They adapt and modify the poetic and metric principles of the hymns in other languages (Laitinen 2005; see also Kallio 2016; Lehtonen \& Kallio 2017). While the hymns by Finno are based on iambic models, they contain a great number of verses of ambiguous or trochaic character (Kurvinen 1941: 23-24). The first stanza of the hymn "De profundis" is a good example of this ambiguity. In the transcription into modern orthography in the second column below, the syllables in bold show one interpretation of how the stresses of the poem could be emphasised as near to the original metric pattern by Luther as possible. ${ }^{3}$ Yet, some verses simply may not be interpreted as iambic lines with the same amounts of stresses as the original version.

Sinun tyghös Herra tulen

Ja huudhan syuäs waiuas,

Aua koruas änen cule

Älä must erkane cauuas

Jos sinä syndi tutkistel

Ja wäärytt tadhot luieskel

Cuca woij sinun edhesäs pysy.

(Finno 1988: 213)

I come to you my Lord

and cry in deep trouble.

Open your ears, hear my voice

do not diverge far from me.

If you examine the $\sin (\mathrm{s})$

and were to mark iniquities

who shall stand in front of you?
Sinun tykös Herra tulen, ja huudan syväs vaivas, avaa korvas äänen kuule, älä must erkane kauas. ${ }^{\circ}$ Jos sinä syntii tutkistel, ja vääryyt tahdot lueskel, kuka voi sinun edessäs pysyy?

Finno wrote the hymn in close relation to the versification of the biblical psalm 130 by Martin Luther and the Swedish translation. The original verses by Luther are strictly iambic, with a stanza structure of 7- and 8-syllabic verses (8787887) connected by a rhyme (ababccb). Finno's verses vary between 7 and 10 syllables, and the last verse is often left without rhyme (Hallio 1936: 380). In the first stanza above, the first and third verses are good examples of the trochaic verse of eight syllables set along the iambic 8-syllable pattern of the German origin, while the rest of the stanza is interpretable along the basic iambic pattern. Contrary to the original German hymn, two light syllables are allowed in non-stressed poetic positions (Cuca woij sinun edhesäs pysy). Thus, while some verses do not confine to the iambic metre of the original German 
hymn, most of the verses may be read as adapting this pattern. In Finnish seventeenth-century musical manuscripts, the hymn by Finno was given the very same melody used by Luther in his hymn (VVE 60). Thus, the Finnish poem was set to the same musical pattern as the strictly iambic German one. Evidently, the Finnish trochaic verses were simply set into musical structure in a syllabic fashion, without bothering too much of the actual stresses. As noted by Heikki Laitinen (2003: 183, 211; 2005: 156), there is no technical difficulty in singing an occasional trochaic verse along the iambic ones. Here, the melody and the clerical knowledge of the hymns in other languages may also have supported the interpretation and understanding of ambiguous Finnish poetic structures.

All the 101 hymns of the first Finnish hymnal are far away from the style of runo-songs, with almost an overstated avoidance of alliteration that, on the average, only occurs in 14\% of the verses (Lehtonen 2016: 205). This is not surprising as the Lutheran hymns in Europe were composed with rhymes and stanzas. It has been estimated that their popular stanzaic melodies and familiar poetic forms were one factor in the success of the Reformation (Brown 2005). Even technically, the old oral Finnish metre would not have been compatible with all the melodies and verse types of various lengths of the Lutheran hymns in other languages. Nevertheless, it has been debatable whether the choice by Finno related more to his explicit wish to join the Lutheran singing tradition in other languages (as he said) or to some disdain for the aesthetics or ungodly associations carried by the traditional Finnish oral idiom (see Finno 1988; Häkkinen 2012: 21-22; Kallio 2016).

Yet, around the publication of the first Finnish hymnal, some unknown writer in the Finnish parish of Stockholm wrote two peculiar hymns in a manuscript. The poems are rather free translations of medieval Latin hymns (benedicamus), which were written with rhymed couplets in iambic tetrametre, with a refrain "Hallelluia, hallelluia" to be sung after each verse. In the Finnish manuscript the refrain is indicated by "Halle" after the first verse (Rapola 1934; Kurvinen 1929: 204, 355-356). The simple two-line melody given to these songs in the Finnish seventeenth-century manuscripts has an explicit rhythmical place for every metrical position (VVE 123). The pattern of rhyme (aabbcc...), although it appears in both Finnish poems, is not stable. In the marking system the same principles are followed as in the previous example.

Hyuä herra herra christ, Halle, Hyvä herra herra Krist, Halle,

Se suuri cunnian cuningas Se suuri kunnian kuningas

Is [ens] $]^{4}$ tahdon täytti tääll, Isäns tahdon täytti tääll [Ja] iellens päsi wallan pääll ja iellens pääsi vallan pääll 


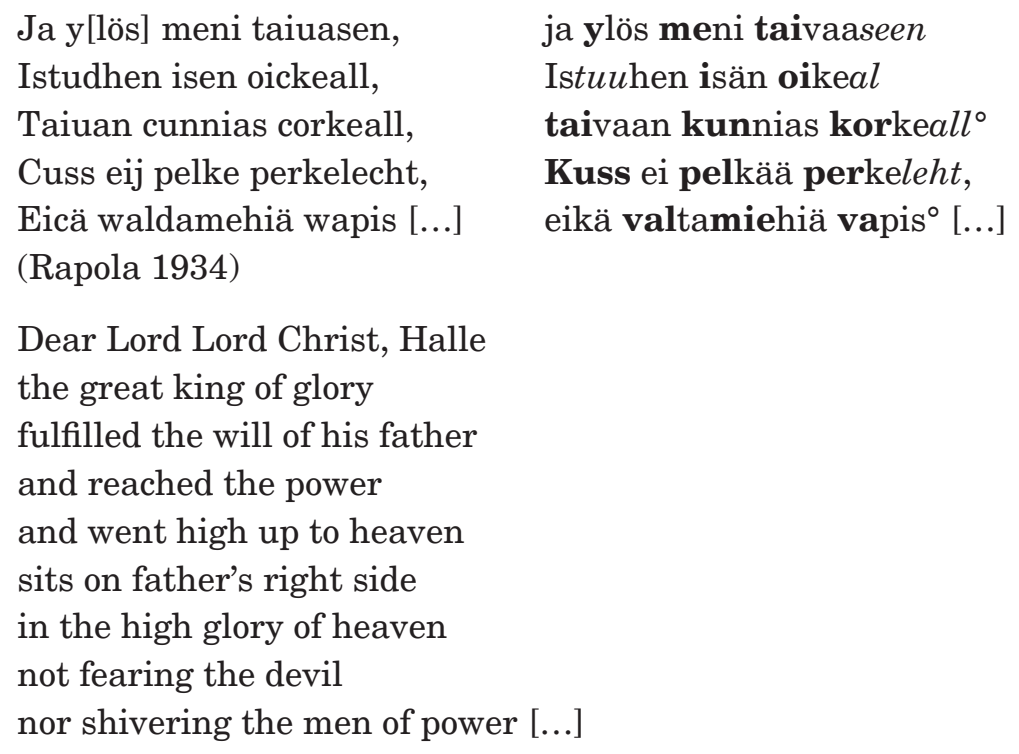

While creating his verses to fit into iambic poetic model and particular melodic pattern, the anonymous writer has made excessive use of runo-song stylistics. $98 \%$ of the verses contain strong or weak alliteration. It is more than in Finnic oral epics, where the average amount of alliterated verses is around $80 \%$ (Leino 1986: 134; see also Frog \& Stepanova 2011: 200). Moreover, the metre of the poem is a peculiar hybrid. It looks like the anonymous writer would first have thought of verses in Kalevala-metre, and then either reduced one syllable from the end of each trochaic verse or taken the iamb-like broken verses as such. Just to demonstrate the likeness, it is possible to interpret the verses into nearly flawless oral-like Kalevala-metre just by adding some final syllables [in brackets], without any changes in the meanings of the verses. The text below is transcribed into modern orthography, with stressed syllables in bold and those few not confining to the constraints of Kalevala-metre italicised: ${ }^{5}$

Hyvä herra herra Krist[us], se suuri kunnian kuningas, isäns tahdon täytti tääll[ä], ja iellens pääsi vallan pääll[ä], ja ylös meni taiva[h]asen, istuuhen $i$ sän oikeall[a], taivaan kunnias korkeall[a], kuss ei pelkää perkeleht[ä], eikä valtamiehiä vapis[e]... 
On the other hand, due to the broken verses and rather free structure of the first poetic foot of Kalevala-metre, and to the skillful modifications by the author, the poem fits equally to a loose iambic scheme with only some deviant lines:

\begin{tabular}{|l|l|l|l|}
\hline$(-)+$ & -+ & -+ & -+ \\
\hline Hy- & vä her- & ra her- & ra Christ, \\
\hline Se suu- & ri kun- & nian ku- & ningas \\
\hline I- & säns tah- & don täyt- & ti tääll, \\
\hline Ja iel- & lens pää- & si val- & lan pääll \\
\hline Ja y- & lös me- & n[i] tai- & vaaseen, ${ }^{\circ}$ \\
\hline Istuu- & hen i- & sän oi- & keall, \\
\hline Tai- & vaan kun- & nias kor- & keall, \\
\hline Kuss & ei pel- & kää per- & keleht, \\
\hline Eikä val- & tamie- & hiä & vapis ${ }^{\circ}[. .]$. \\
\hline
\end{tabular}

The first foot is filled rather freely, often only with one syllable and sometimes with iambic inversion (istudhen, and later in the poem). In singing, it is easy to lengthen the first syllable to fill two poetic positions. In my experience, the text works fine as a song.

Thus, in this case, it seems that Kalevala-metre has served as a kind of reworkable sub-structure, convertible into and partly interpretable as an iambic form. The unknown writer found a way to combine familiar, traditional elements into the new iambic, rhymed structure, making an intricate hybrid form. Apparently, the poem itself is thought to refer to the iambic model of the Latin poem and to be sung with similar melodies and refrains. Compared to the avoidance of alliteration in the first Finnish hymnal, these two poems in the manuscript, with excessive alliteration and loose pattern of rhyme, seem to indicate very different opinions on how to build Lutheran singing in Finnish. Although there are no sources describing the process and possible controversies of creating Finnish Lutheran hymns, the research on the controversies around the ecclesiastical practices, rituals, and church services in the Kingdom of Sweden gives a solid evidence of the unstable, animate associations attached in varying ways to different religious symbols and practices. It was not always clear where the borders between Lutheran, Catholic, Calvinistic, heathen, and ungodly practices and references would lie (Berntson 2016; Lehtonen \& Kallio 2017). It is also possible that there has been much variation in the understandings and interpretations of the status, meanings, and possibilities of traditional Finnish runo-song poetics. In any case, these two hymns seem to mark a turning point. 
In the second edition of the Finnish hymnal from 1605, the new hymns by Hemmingius of Masku and Petrus Melartopaeus made free use of alliteration and some patterns of stress typical of the oral idiom, combining these to rhymes, stanzas, and mostly iambic models of hymns in other languages. Contrary to the first hymnal, the second one also contained some clearly trochaic songs (Kurvinen 1929; Kallio 2015b, 2016; Laitinen 2005). Yet, older hymns by Finno were also included. Hemmingius also published new versions of those two alliterative songs of the anonymous manuscript. He slightly modified the content according to the rising Lutheran Orthodox standards, ${ }^{6}$ and regularised the pattern of rhyme, while keeping a similar poetic style and most of the previous verses. Nevertheless, while the anonymous poet used only verses of 7-8 syllables, Hemmingius added lines of 7-11 syllables (VKK Hemm1605-152; see also Kurvinen 1929: 355-356; Lehtonen \& Kallio 2017: 189).

Jacobus Finno made his admiration for German hymns and Lutheran singing culture explicit (Lehtonen 2016), but, in fact, his followers may have been closer to the original idea of Martin Luther to use a song language that would be familiar and affective to the local vernacular congregations. While rhymed, stanzaic poetry was already in wide use and familiar in Central Europe, the Finnish congregations may have felt the use of alliteration and references to runo-songs more affective. In fact, it seems that slightly earlier a rather similar process took place in Iceland, where the first Lutheran hymnal (1555) followed strictly the German rhymed poetics, while the second one (1589) made use of ample alliteration and other familiar patterns of Icelandic vernacular poetry (Eggertsdóttir 2006: 179-180).

Yet, across all the variation, the Lutheran hymn makers seem to have been consistent in making the Finnish hymn registers different from traditional oral runo-songs. Even when using the most explicit features of traditional oral poetics, they mixed these with other ones - such as rhyme, longer or shorter verses, refrains, stanza patterns, and melodies - that defined the register of hymns and marked it to be something else than the old runo-song tradition. Lutheran hymns needed to have rhymes and used melodies similar to those in other countries.

\section{RHYMED COUPLET AND KALEVALA-METRE}

The early history of Finnish literary poems is in many ways similar and coincident with the creation of Lutheran hymns. This is not surprising, since the first Finnish literary poems were made by the very same clergymen and 
published in the prefaces of hymnals and other ecclesiastical books. Yet, the relation of new forms to old oral poetics took a slightly different route than in hymns. In literary poems, the sixteenth-century avoidance of alliteration and other runo-song stylistics changed not only to the seventeenth-century use of various hybrid forms, but, by the end of the century, into full application of oral-like Kalevala-metre.

The first known literary poems in Finnish were written and published by Mikael Agricola in 1543-1551. He wrote prefaces in verse to Catechetical primer, prayer book, psalter, and two translations from the Old Testament (Häkkinen 2012; 2015: 59). Similarly to the hymns he published, these poems bear no references to runo-songs. In the prefaces, Agricola uses a loose poetic pattern of rhymed couplets. His lines consist of 8-10 syllables, occasionally of 11 syllables. No alliteration similar to runo-songs is used. The rhymes are sometimes vowel rhymes (tekee/rukoele) or other types of half-rhymes (hylkää/sylkee). It seems this metre should be understood as loose accentual verse of four stresses with optional anacrusis, created as a Finnish adaptation of the Swedish and German knittel-verse (Häkkinen 2012: 20-26; Lilja 2003, 2006; Widoff 2013), although some lines are difficult to interpret. Below, the unambiguously stressed syllables are in bold, while the words of only one syllable and some light words of two syllables might be interpreted either stressed (in bold and italicised) or non-stressed. Verses with several interpretive possibilities are marked with ${ }^{\circ}$ :

NYt on se waralinen aijca. Nyt on se vaaralinen aika, quin iocapaijcas cwlu maalla kuin jokapaikas kuuluu maalla, Josta Christus ia Apostolit. josta Kristus ja apostolit, ${ }^{\circ}$ hartast puhuijt ia cwlutit. hartaast puhuit ja kuulutit. ${ }^{\circ}$ Etteij ollut Mailman alghust. Ettei ollut mailman algust, Swremat tuskat, quin ouat lopust. suuremmat tuskat, kuin ovat lopust. Sille se, ioca tachto wältte. Sillä se, joka tahtoo välttää, Herran wiha, ia Tulen heltte. Herran vihaa, ja tulen helttä, Se alati sijs rucolkan. se alati siis rukolkaan, ${ }^{\circ}$ ia Jumalan armo anokan. ja Jumalan armoo anokaan. ${ }^{\circ 7}$ (Agricola 1987: 90)

Now is that dangerous time when everywhere on the land is heard, what the Christ and the apostles earnestly spoke and proclaimed: that at the beginning of the world there were no greater pains than there are at the end. 
Thus, who wants to avoid

Lord's anger and the heat of the fire, should persistently pray and plead for God's mercy.

Most verses $(1,2,5-8)$ fit into the general pattern of accentual lines of four stresses and an optional amount (1-3) on unstressed syllables in-between, while some occasional lines with 8-9 syllables and only 3 unambiguous main stresses (in verses $3,4,9,10$ ) pose an interpretive problem. These may be understood as verses with masculine endings (hartast puhuijt ia cwlutit; Se alati sijs rucolkan). In Swedish medieval and early modern knittel-verse, it is possible to have lines of only three stresses or lines with masculine endings on excessive syllables, but, typically, these occur in couplets of two similar verses (Lilja 2006: 210-213, 442-445). The irregular verses of Agricola often occur in pairs, but not always.

On the other hand, if compared with the early Finnish hymn poetics, it may be asked whether Agricola or his intended audiences might have interpreted some short irregular lines along more syllabic principles, regardless of actual stresses. In this case, the verses like the two last ones above might be interpreted similarly to Kalevala-metric broken verses (se a-|lati| siis ru-|koilkaan) or even with no emphasis on some stressed long syllables (as the syllable 'ar' in the verse "ja| Juma-|lan ar-| mo a-|nokan"). This interpretation would liken to the way some early hymn structures need to be interpreted when verses with various patterns of stress were applied to the same recurrent melodic schemes (and, supposedly, along the more regular models in other languages). Naturally, it is probable that the poems of the prefaces were never used as songs. The versatile patterns in both early hymns and literary poems sometimes allow several metrical interpretations, and often it is simply beyond reach to know how the hymn verses were set into melodic patterns or how the literary rhythms were understood. There may even have been competing contemporary understandings.

Agricola's poems are the first link in the chain of literary poems in Finnish. Similar loose accentual patterns appear in other literary poems as well, but, in addition, some of his successors combined the structure of rhymed couplet with more or less explicit features of Kalevala-metre. The most distinctive and frequent of these features is the use of alliteration.

After Agricola, the next preface in verse appeared in the second edition of the Finnish hymnal in 1605, written by Hemmingius of Masku. Hemmingius used a strict pattern of regular trochaic verses with caesura, highlighted by typological means. In the transcription, the syllables with poetic stress are in bold. 
[...] Äläs ennen näitä laita,

Edk he heicod olla taita,

Cuin caunimbit edhes tuodan,

Jotc sun saavas kyllä suodan.

Mester Jacoin jalo lue,

Ennen tehty esipuhe, [...]

(Maskulainen 1607)
[...] Äläs ennen näitä laita, etk he heikot olla taitaa, kuin kaunimbit etees tuodaan, jotk sun saavas kyllä suodaan.

Mester Jaakoin jalo lue, ennen tehty esipuhe [...]

[...] Do not blame these [verses], although they may be weak, until more beautiful ones are brought to you that you hopefully will have.

Read the noble, by the Master Jacob, previously made preface [...]

The poem consists of accentual-syllabic trochee with no broken verses. Both ample alliteration and regular rhyme are in use. Occasional stressed syllables are allowed in weak positions especially at the first foot (Cuin caunimbit), and long stressed syllables are used interchangeably with short stressed syllables in stressed poetic positions. The metre could be interpreted as a literary, rhymed, accentual, trochaic version of oral runo-songs, or as a syllabised, alliterated, trochaic version of accentual rhymed couplets. The use of rhyme and strictly trochaic, accentual structure with typographically marked caesura in every verse sets the poem apart from the traditional oral runo-song, although the similarities are striking. Contrary to Agricola and Jacobus Finno, Hemmingius of Masku used alliteration, occasional Kalevala-metric verse structures and references to formulae on oral tradition in various degrees also in his hymns, although rarely as explicitly as in his preface (see VKK Hemm1605; Kallio 2016; Lehtonen 2013: 127-133; Lehtonen \& Kallio 2017; Laitinen 2005). It is remarkable that while the amount of syllables in the hymn verses by Hemmingius occasionally varies considerably, in the preface he shows himself as capable of making strictly measured verses, while at the same time expressing conventional apologies on the incomplete character of the poems.

A similar kind of combination of different poetics is evident in the greeting poem by Olaus Georgii Suomalainen for the weddings of the headmaster of the cathedral school in Åbo in 1609. Here and in the following examples syllables with main stress are in bold, short stressed ones also italicised:

Hoy, hoy suosinen Sukuni!

Quing niin vnhodhat Ukuni?

Fyiffyi ${ }^{8}$ Poutack vaiko halla
Hoi, hoi suosinen sukuni!

Kuink niin unhohdat $\boldsymbol{u}$ kuni?

Fyiffyi poutak vaiko halla 
Mick on olla Suomen-maalla

Ettei siellä löytä enää

Tervett kättä taikka nenää [...]

(Suomi 1963: 261)

Ohoy, ohoy my favourable kin!

How may you forget my lament?

Fyi-fyi dry weather or frost,

how is it in Finland,

that one finds no more

a sound hand or nose [...]
Mik on olla Suomen-maalla

Ettei siellä löydä enää

Tervett kättä taikka nenää [...]

Contrary to Hemmingius of Masku, Suomalainen uses also occasional broken verses (verses 1-2 above) typical of Kalevala-metre. Similarly to many learned applications and also oral metre in western Finland, he allows short stressed syllables both in strong and weak (verses 5-6) positions (Laitinen 2006: 38; Leino 2002 [1975]: 212). The poem makes use of both alliteration and rhyme (Kallio 2015b). As the English translation leads to suggest, the syntax of the poem is rather complicated. Although it is not the focus of the present article, it is evident that the syntax in these early modern literary poems is often rather complex and difficult to follow, and this is common also in hymns, where, as in the oral runo-song tradition, the syntax is typically rather straightforward and in closer relation to verse structure. ${ }^{9}$

In some learned poems, this kind of alliterative, rhymed, regular, and mostly trochaic metre with occasional broken verses was explicitly connected to the old oral tradition by using the label runo. The most obvious example is the congratulatory poem of 31 verses by Ericus Justander to King Carl X Gustaf in 1654, given the title "Imitation of ancient Finnish runo-songs" (Imitatio Antiquorum Tavvast-Finnonicorum Runorum):

Hywä Herra CARL Cuningas,

Ruotzin röykiä Ruhtinas,

Lähdätti Lawiat Laiwat,

Pani Pyssyt päälle parhat,

Huilut Harput Helisemän,

Trumbut tuimat tömisemän,

[...]

(Melander 1928: 50)

Dear Lord King Karl, the mighty Prince of Sweden,
Hyvä herra Karl kuningas, Ruotsin röykiä ruhtinas, lähdätti laviat laivat, pani pyssyt päälle parhaat, huilut harput helisemään, trumbut tuimat tömisemään, [...] 
sent the large ships,

loaded with the best guns,

with flutes, harps to tinkle,

with severe drums to thunder [...]

Justander, who later obtained the professorship of poetics in Åbo (see Melander 1928: 13-14), used excessive alliteration in all but two of the verses, the exact amount of eight syllables in every verse, and rhyme in every couplet. The short stressed syllables are used both in strong (lines 5 \& 6 ) and weak positions (lines $1 \& 3$ ), and occasional long stressed syllables are allowed in weak positions (line 2, 'ruhtinas'). The syntax of the poem is simpler than in most of the early modern literary poems.

The metrics and poetics of the alliterated rhymed couplet vary by writers. The poems by Hemmingius of Masku and Ericus Justander represent most regular versions in regard to the amounts of syllables and the patterns of stress, although they made different choices on broken verses. Some other poems, for example the first rhymed chronicle in Finnish, the Ajan-Tieto (1658) by Laurentius Petri (VKK LPet1658), and the Christian teaching HuoneenSpeili (1699) by Jonas Mennander (VKK Menn1699), make use of somewhat looser versions of alliterated rhymed couplet. Contrary to others, Mennander uses alliteration rather moderately. The poems are built on accentual trochaic verses of mainly 810 syllables, based on syllabic stress only, while the broken verses of Kalevala-metre are in most cases avoided. Towards the end of these long poems, the stress patterns become more irregular.

It was not until the second half of the seventeenth century that the clergymen began to use oral-like forms of Kalevala-metre without rhymes in their literary poems. This seems to indicate one more change in the relation of literary genres to oral poetics. This change was conducted by several clergymen mainly from Ostrobothnia and Kainuu in northern and eastern Finland. They shared a new understanding of the possibilities to use the oral-like unrhymed metre and poetics in literary contexts. This may be partly due to the antiquarian interests of the time, which slowly changed the status of traditional expressions (Widenberg 2006), and partly due to the fact that the oral poetics in Ostrobothnia, Kainuu, and Karelia was evidently more uniform and regular than in western Finland (Sarajas 1956: 54-58, 86-88; Laitinen 2006: 53).

A most well-known example of literary uses of oral-like poetics is the Messiah Ilo-laulu Jesuxesta of 2265 verses in nearly flawless unrhymed Kalevala-metre, published by the Lutheran priest Matthias Salamnius in 1690: 
Cansa outoia anopi, Ikäwöitse Ilma caicki;

Menot curiat cuultaxensa, Saadansa Sadat sanomat: Waan ei tottele tosia, Tutki tarpehellisia; Cuinga culki suuri HErra, Luoja itsensä alensi, [...]
Kansa outoja anoopi, Ikävöitsee ilma kaikki Menot kurjat kuullaksensa, Saadansa sadat sanomat, Vaan ei tottele tosia, Tutki tarpehellisia, Kuinka kulki suuri Herra, Luoja itsensä alensi [...]

The people ask for odd things

all the air is yarning, to hear some doomed practices, to get hundreds of sayings, but does not obey the true (sayings), examine the needed ones:

How did set out the great Lord, the Creator did low himself [...]

The poem became very popular, it was re-printed several times, and in oral versions it was offered to the nineteenth-century folklore collectors as a fine example of traditional Finnish poetry (Laitinen 2006: 53-54). In his lengthy preface, Salamnius gives some illuminating remarks:

It should not be considered strange that this is written in Runoi verses (Runoi wärsyillä) that are very familiar among Finns. [...] Even though we finely know that many illicit matters have been composed and sung in this kind of runo-songs (runolauluin), it would not help more [to not to use the poetic form] than to throw away the common speech for the reason that it is used in incorrect ways. (Salamnius 1690: preface)

Salamnius also states he has done the work with the encouragement and (financial) help of Bishop Johan Gezelius, who was known for his very strictly condemning attitudes to vernacular beliefs. This clearly indicates that the use of the traditional unrhymed oral metre was subject to contradictions and discussions, but, towards the end of the seventeenth century, accepted fully as an efficient means to convey Christian teaching to "the simple folk", as expressed by Salamnius (ibid.). 


\section{AMBIGUITY OF POETIC PATTERNS}

The blurred boundaries between poetic forms are clearly present in the seventeenth-century poetic descriptions. Aeschillus Petraeus, professor of theology, headmaster of the Åbo Academy and later the bishop of Åbo, wrote the first lengthy description of Finnish poetics in his Finnish grammar in 1649. This description is short, general, and somewhat confusing: Petraeus (1968 [1649]: 65-66) says that Finnish poetry is based on rhyme, but often also uses alliteration. He says the quantity of syllables is not observed, and tells nothing of the length of the lines. Indeed, this description applies to most of the ambiguous hymns in the first two Finnish hymnals, and rather well to most of the Finnish poetry written in the 17th century. The contemporary Finnish rhymed poetry was based on various European stanzaic models, but the constraints of stress and number of syllables were rather loose. If the description is meant to depict also Kalevala-metre, it shows the difficulty to understand the constraints on both the length and stress of syllables. If Petraeus had classic Latin metrics or the new vernacular poetics of Martin Opitz in mind, it is evident there was no similar regularity in Finnish poetry.

While the description of Finnish poetics is vague, the set of examples is encompassing and precise: first a trochaic and very alliterative hymn with rhymes by Hemmingius of Masku, then a more or less iambic hymn with rhymes by Jacobus Finno, eight oral-like riddles and one proverb from an unknown source, and finally the oral-styled proverb and rote (that relate to Kalevala-metre but do not follow the metrical constraints strictly) from Agricola's prayer book (Petraeus 1968 [1649]: 65-72; Kallio 2015b: 16-19). Although the description is short and general, this selection of examples shows a detailed understanding of various poetic types that existed in the Finnish early modern poetry. Yet, across the examples, Petraeus seemed to prefer poems that contain both alliteration (even the one by Finno) and some kind of rhyme, with verses of 7-10 syllables.

Above all, Petraeus emphasised the importance of rhyme, describing it as an obligatory part of Finnish poems. Some of his riddles contradicted this claim, but the last three ones of these Kalevala-metric riddles used parallelism that, due to similar grammatical forms, caused some rhymes: "Lyhykäinen lylleröinen, tasapäinen talleroinen, carjan corvesta cocopi" ("The short one, the even one, collects the cattle from the forest'). Most remarkably, Petraeus modified the two oral-like texts from Agricola into more rhyme-like form at the expense of the metrical structure: "Satehixi peijuen sappi, Poudixi Cuum kehä" $\rightarrow$ "Päiwän sappi satehexi, Cuun kehä poudixi ('The halo of the sun brings rain, the halo of the moon brings fair weather'). On the other hand, the trochaic hymn by Hemmingius is one of those that most resembles traditional oral runo-songs. 
Already Julius Krohn noted that Hemmingius seems to move closest to traditional oral poetics and Kalevala-metre when making his own compositions (such as the one cited here) and when translating trochaic songs (Krohn 1862: 38; see also Kallio et al. 2017).

It has been estimated that Petraeus - who was born and had studied in Sweden, and, thus, did not speak Finnish as his mother tongue - either did not understand Finnish poetics or wanted to efface the characteristics of traditional runo-songs (Sarajas 1956: 40-42). On the basis of his Kalevala-metric oral-styled riddles, the latter assumption does not seem to hold: he could have made his description with hymns only. It is equally evident that, as the head of the Academy of Åbo, he had the best Finnish clerical scholars at his disposal to help him understand the Finnish language and poetics - and, indeed, the selection of examples is remarkably representative. It seems more plausible that the rules of oral poetry were just too complicated and too far away from classical Latin poetics to be understood theoretically in the early modern context. In fact, the quantity rules of the Kalevala-metre were not properly described until the nineteenth century (Haapanen 1928; Kuusi 1994: 42), and the loose early modern hymn metrics and the evident variation of oral Kalevala-metre did not make the situation any clearer.

Moreover, the Finnish grammar by Petraeus was not a scholarly treatise, but a short practical guide (Linguae Finnicae Brevis Institutio) for officials coming from other regions and in need of learning the basics of the Finnish language, as was typical of early vernacular grammars (Lauerma 2012). He was not aiming to describe Finnish folk poetry or traditional metre, but gave a general characterisation that encompassed different genres and forms of his contemporary poetry. While doing this, Petraeus also showed that, by his time, alliteration was a thoroughly approved feature of all Finnish poetry. Along with his geographical location (western variations of Kalevala-metre), the focus on all contemporary Finnish poetry explains why Petraeus did not follow the short description of Kalevala-metre by Johannes Bureus (Johan Bure) written already in 1626. Bureus emphasised the importance of alliteration, defined the poetic lines to consist of eight syllables, and did not mention rhyme (Bure 1626: 15). Thus, he depicted the traditional unrhymed Kalevala-metre in its most regular eight-syllable form. Bureus had been working in southern Karelia, were, on the basis of later sources, the metre of the oral runo-songs seems to have been more uniform and regular than in western Finland (Sarajas 1956: 31-32).

Just a year after Petraeus, his colleague Michael Wexionius, professor of law in Åbo, mentions in his book on geography that the Finns do not appreciate or even recognise a poem if it does not alliterate. Even more interestingly, Wexionius cites three trochaic, alliterative verses from another hymn by Hemmingius 
of Masku, and goes on to explain that these kinds of runo-songs (Runoi) used to have only one ancient melody. ${ }^{10}$ This comment seems to indicate that at least the trochaic alliterative hymn verses (with rhymes) may have been understood as a continuum of traditional Finnish runo-songs. The cited verses contain seven syllables each, the last syllables abbreviated (pauhatkat[te]):

Pojat parhat pauhatkat,

Neitzet nuoret iloitkat,

Vanhat vahvast veisatkat.

(Wexionius 1650: vol. 3, s. 14)

Ring out, the best boys,

Rejoice, the young maidens,

Sing strongly, the old ones.
Pojat parhaat pauhatkaat, Neitset nuoret iloitkaat, Vanhat vahvast veisatkaat.

Indeed, especially if added with the abbreviated syllables, these verses would pass as nearly flawless normal verses of Kalevala-metre just with one short stressed syllable (iloitkat) in strong metrical position. The cited verses form the third stanza of the hymn. In the second Finnish hymnal from 1605, the structure of the song was built on these kinds of rhymed three-verse stanzas and a long alliterative refrain of trochaic verses of mostly 11 syllables:

Jesus caunis helmas macais Maarian.

Gabrielin ennustos on täytetty, Eija, Eija, Neidzy nuori sikjän sai, Ilman miehet Pojan toi, qvin caicki loi, Tydhy tähän pilttin vähän, pilttin vähän, Israel,

Älä lunastajat toista toevo sill.

Tosin cunnjan Cuningas Emanuel, Neidzest nuorest syndyi, sanoi Gabriel.

(VKK Hemm1605-135:1)

Beautiful Jesus lay in the lap of Mary.

The prediction of Gabriel is fulfilled, Eija, Eija, a virgin bore a child, The men of air brought a son, he created all, Be content with this small child, Israel, Do not wish for another redeemer.

The true king of glory Immanuel, was born of a young virgin, told Gabriel.

The song is built according to the melodic and poetic pattern of the medieval Latin original, Resonet in laudibus (Hallio 1936: 34-35; VVE 92). Contrary to 
the stanzas of three verses, the poetic pattern of the long refrain could hardly be understood in any continuum of Kalevala-metre. Yet, similarly to Petraeus, Wexionius was apt to pick some of the most Kalevala-metre-like trochaic verses of the whole hymnal.

Thus, Michael Wexionius set some hymn verses by Hemmingius into the continuum with traditional Finnish runo-songs. Ericus Justander, as shown above, named his literary rhymed couplets as imitations of ancient Finnish runo-songs. What is common to both of these examples is the combination of alliteration and rhyme with a reference to traditional Finnish poetic form. Where the chosen verses by Hemmingius are built on accentuated trochee of seven-syllable verses and no broken verses, Justander used some broken verses in his strictly eight-syllable lines. Thus, in the contemporary conception, the rhymed alliterated poems, in different variations, were understood as versions of traditional Finnish runo-songs or as belonging to the same continuum, even if the metre was not exactly what we understand by Kalevala-metre. On the other hand, the two oral-derived texts in the prayer book (1544) and some of the riddles chosen by Petraeus did not represent most regular forms of Kalevalametre either.

Indeed, it is evident that the concept of Kalevala-metre, as it is understood nowadays, did not exist in early modern Finland. Whereas for a modern scholar the metre seems rather well described and defined, this was not the case for early modern scholars. They did not have theoretical means to understand the vernacular metre that, moreover, seemed to have lived in a rather large scale of different oral versions in western Finland. Yet, the literary versions of runosongs, with rhymes and with varying constraints on stressed syllables, should not be seen as a general misunderstanding only. It is possible that the authors were consciously creating new poetic registers, and were only aiming to refer to the traditional oral metre, not trying to make exact replicas but literary, contemporary versions or imitations thereof. Depending on the context, this strategy might have been an efficient way to introduce the new Lutheran hymns, highlight the antiquarian value of local traditions, and change the poetic form enough to get rid of the possible obscene or ungodly associations related to the local folk poetry, hinted at by Salamnius. Yet, some variation in the uses and interpretations may also derive from the character of Kalevala-metre itself.

Indeed, the basic structure of Kalevala-metre gives at least three possibilities for confusion. As explained earlier, there are two types of verses in the metre: normal and broken verses. If we read according to accentual principles, normal verses are evidently trochaic, while the broken verses may greatly resemble iambic verses. Yet, this is not the only ambivalent character of Kalevala-metre. 
The flexibility of the beginning of the verse is another significant feature: the first poetic foot may contain 2-4 syllables, and the constraints of stress and length do not count here, although, if filled with more than two syllables, the additional ones tend to be light. In addition, it is usually rather easy to contract the last syllable of the verse without making the words incomprehensible or the metre unrecognisable, which means even more possibilities for variation. In western dialects and especially in spoken genres, the last syllables of the lines and even of some words in the middle of lines were sometimes shortened, meaning a runo-song verse could appear in the form of only 5-7 syllables. ${ }^{11}$ These factors made it possible for the unknown writer in the Finnish congregation of Stockholm to translate two iambic Latin hymns with the structures drawing from Kalevala-metre.

A third confusing feature is that even though traditional runo-songs do not use structural rhyme, occasional ones may appear as a result of parallel verses and the structure of language that uses an abundance of suffixes. A good example of this is a proverb or proverbial poem by prospective Bishop Olaus Elimaeus, written in the autograph album of Axel Oxenstierna at the University of Rostock in 1602:

Etzi wisaus wisusta

Tawat tutki taitawasta

Nijn sä mailla mainitahan

Monin paikoin paluellahan.

(Nuorteva 1997: 25-26)

Search steadily for wisdom,

Examine the manners with skill,

So you will be mentioned (everywhere)

Will be served in many places.
Etsi viisaus visusta, tavat tutki taitavasta, niin sä mailla mainitahan, monin paikoin palvellahan.

The metre of the poem is regular Kalevala-metre with one broken verse at the beginning. Yet, the parallel structure $(2+2$ verses $)$ with similar grammatical forms enables or creates also a pattern of rhyme (aabb). Elimaeus used another version of the same theme with a similar structure in another autograph book in 1613 (ibid.). These poems may be read simultaneously as verses of a traditional unrhymed, non-stanzaic runo-song (with occasional rhymes caused by the parallel structures) or as beautiful stanzas of two rhymed couplets. This double character may well have been the intention of the writer.

The confusing constitution of the traditional Finnish metre may also have affected the ways the early modern hymn makers thought of the overall possibilities of creating Finnish poetry. The rules of stress and length of syllables 
in Kalevala-metre were not verbalised until the nineteenth century (although they were more or less intuitively understood by many writers). In addition, the Kalevala-metre in western Finland allowed the placement of short stressed syllables both in stressed and unstressed poetic positions. In practice, different vernacular genres made use of both the regular Kalevala-metre and looser and shorter forms. On the basis of these factors, the Lutheran hymn writers in western Finland might have understood it possible to create new genres of rhymed poetry according to even more flexible versification than was common in vernacular hymns in other languages. If they thought that traditional oral Kalevala-metre consisted of freely alternating trochaic and iambic verses, or that oral Kalevala-metre paid little attention to exact patterns of stress, it would not be surprising they used some trochaic verses in mostly iambic rhymed hymns freely.

Nevertheless, taken together with the unrhymed poem in Kalevala-metre by Matthias Salamnius and the comments he gives in the preface, this history of literary adaptations or understandings of the oral poetic forms poses some difficult questions. Salamnius explicitly defends his choice of using the runosong metre, and indeed, he is the first one to use unrhymed Kalevala-metre in a thoroughly Lutheran poem that was intended for the common folk. Before him, the unrhymed metre was used only in some learned occasional poems by clergymen from Ostrobothnia and Kainuu (Sarajas 1956: 54-58). His need to defend the use of the oral-like metre gives another shade to the discussion on the borders between poetic forms and genres. Were the opinions on form, status, and applicability of the traditional Finnish metre in constant flux? On the basis of sharp changes in the use of alliteration during the sixteenth century, the appropriate uses of different poetic forms and features might have been a contested issue, and the appropriate form of 'traditional Finnish poems' in literary contexts might have been contested as well.

Adding alliteration to the rhymed hymns may have been a means to make the hymns more affective to common folk, while adding rhyme and modifying the traditional poetic form may have been one way to make it more acceptable or affective in literary, clerical contexts. This would mean that the combination of rhyme, trochaic verse, and alliteration by Hemmingius, Justander, and others actually was a creation of a new poetic register, which was still understood as belonging to the continuum of the runo-song tradition, while bearing more appropriate Lutheran, literary or sophisticated associations. In any case, it is evident that almost forty years after the famous "Imitation of ancient Finnish runo-songs" by Justander, there was still a need to justify the use of the traditional unrhymed form of poetry in literary context. 


\section{HYBRID POETIC REGISTERS}

These early modern examples show a very complex and multifaceted process of creating different poetic registers in Finnish. The material demonstrates the elites had knowledge of oral poetics that they both avoided and applied in various ways. During the seventeenth century, the learned elites created a literary, hybrid version of the traditional runo-songs. This rhymed, alliterated form, which often does not use the so-called 'broken verses' of Kalevala-metre, has frequently been interpreted as a misunderstanding of the traditional oral poetics. In this article it is understood as an intentional, slowly developing hybrid form with a degree of individual variations.

The first poetic prefaces by Mikael Agricola were written in a loose rhymed couplet resembling the medieval Germanic and Scandinavian knittel-verse, and avoiding alliteration. In literary poems, the preface for the second edition of the Finnish hymnal marked a poetic turn. The short poetic preface of the hymnal was written in trochaic, alliterative, rhymed metre, which may be read as a hybrid of Kalevala-metre and a rhymed couplet or knittel-verse or as a literary, rhymed, trochaic version of the old oral metre. From this poem onwards, Kalevala-metric features were incorporated into rhymed couplets - or rhymed couplets were partly built on Kalevala-metre. Yet, apart from the short proverbs by Olaus Elimaeus with rhyme-like features based on parallelism, the first learned poems in traditional unrhymed Kalevala-metre were not published until the last half of the seventeenth century.

The first Finnish hymn writers Mikael Agricola (c. 1510-1557) and Jacobus Finno (1544-1583) avoided explicit features of traditional oral Kalevala-metre, most visible of which were alliteration and the lack of rhymes. A great turn took place first in an anonymous manuscript (Hyuä herra herra christ) in the $1580 \mathrm{~s}$, and then, as with the rhymed couplets, in the second edition of the Finnish hymnal (1605) by Hemmingius of Masku. The manuscript contains two iambic, rhymed, alliterative hymns with a strong Kalevala-metric substructure. In the hymnal, the new songs were mostly written in rhymed stanzas containing plenty of alliteration and parallelism, and occasional Kalevala-metre-like trochaic patterns. In the seventeenth-century poetic descriptions, some most trochaic verses by Hemmingius of Masku were taken as examples or derivatives of traditional Finnish runo-songs.

Thus, in these works, the features of traditional oral Kalevala-metre are, in different ways, incorporated into new ecclesiastical and literary poetic genres. They may be read both as a literarisation of traditional oral poetics and as a cultural adaptation of new poetic forms and genres. Both the various hybrid forms of different poetic systems and the very vague poetic descriptions of the 
seventeenth century lead to suggest that the contemporary interpretations of different poetic forms were rather intuitive and varied. The ambiguity and hybrid character of poems means the contemporary audiences may have interpreted individual poems as a continuum of several poetic traditions.

The publication of more or less Kalevala-metric proverbs from the first Finnish prayer book, the literary rhymed versions of Kalevala-metre and, finally, the use of traditional unrhymed Kalevala-metre at the end of the seventeenth century seems to indicate that the status of the traditional oral poetic form may not have been completely ungodly or inappropriate. Yet, it needs to be remembered that the time frame from the first verses of Agricola to the full oral-like Kalevala-metre of Salamnius is 147 years with a number of political, religious, and ideological changes and struggles. It is evident that there was dissonance and changes in the associations carried by poetic features and registers. On the basis of the early modern poetic descriptions, it seems the most visible (or audible) characteristic features of Finnish poetic registers were rhyme and alliteration. While adding alliteration to the previously un-alliterated hymns may have been an efficient way to familiarise the Finnish congregations with these Lutheran songs, adding rhyme to the imitations of the old oral runo-song metre may have been an efficient way to create a new poetic register appropriate for contemporary, literary, and Lutheran contexts.

\section{ACKNOWLEDGEMENTS}

The article was written within the projects 288119 and 137906 of the Finnish Academy at the Finnish Literature Society. The discussions with, in particular, Heikki Laitinen, Senni Timonen, Kaisa Häkkinen, Elina Heikkilä, Janika Oras, Mari Sarv, Frog, Tuomas Lehtonen, Ilkka Leskelä, Linda Kaljundi, Irma-Riitta Järvinen, and with various colleagues at the conferences The Transformations and Borders of Regilaul (Estonian Literary Museum, 2014) and Frontiers in Comparative Metrics II (University of Tallinn, 2014) were essential in refining the argument.

\section{NOTES}

1 In Finnish scholarship, Kalevala-metre often refers not only to the metre proper, but also to all the most important characteristics of the traditional oral poetic form, including non-structural alliteration, parallelism, lack of stanzas, etc., while in Estonia the meaning is usually confined to the rhythmic and syllabic structure only. The present article follows the former practice. 
${ }^{2}$ In addition to these two main metrical systems, the scholars have also made experiments with classical Latin and Greek metres.

3 The second column gives the text in modern orthography. In the transcription, the syllables with main or secondary stresses are in bold, except in the short words that may, depending on the poetic context, be also interpreted as light ones ('ja', 'jos', 'kuka', 'sinun'), and in the cases of an iambic inversion ('älä must'). Non-stressed syllables that are apparently in strong position are italicised. The aim is to give one option for the rhythmic interpretation of the text in relationship to the used melody-structure and the metre of the original version in German. Verses with several strong interpretive possibilities are marked with ${ }^{\circ}$.

4 Martti Rapola (1934) has added the imperceptible syllables of the manuscript [in brackets] on the basis of a later (1621) printed version.

5 One-syllable words are typically interpreted as non-stressed; 'kuss' in the eighth verse is a shortened form of the two-syllable word 'kussa', and thus marked as stressed.

6 E.g. omitting the formula "the son of Mary" and fading out the emphasis on the Christ as an earthly healer.

7 The transcription into modern Finnish orthography is greatly aided by and almost identical with the one by Kaisa Häkkinen (2012: 51-52).

8 Onomatopoetic syllables for scolding or expressing disgust, a loan from Swedish.

9 Pentti Leino (2002) has compared the metre and syntax in Finnish oral tradition, folk authors and learned writers, and Kristiina Ross (2015) has analysed the syntax and language in Estonian oral tradition and hymns.

10 The term runo or runo-laulu was typically used in literary contexts to denote the traditional Finnish alliterative tetrametre, and the idea of the ancient use of only one melody to sing these songs was a common one also later (Laitinen 2006: 52; Kallio et al. forthcoming).

${ }^{11}$ For example, the proverb "Ah cullaist Coto / armast asuinsia!" (VKK Flor1702-A1a) might be easily expanded to a longer form in Kalevala-metre "Ah on kullaista kotoa, armasta asuinsijoa" ('My golden home, my dear place of dwelling').

\section{ARCHIVAL SOURCES}

SKS KRA - Archives of the Finnish Literature Society (Martta Pelkonen 256, Olonets, Karelia)

\section{REFERENCES}

Agha, Asif 2004. Registers of Language. In: Alessandro Duranti (ed.) A Companion to Linguistic Anthropology. Malden: Blackwell, pp. 23-45. 
Agha, Asif 2007. Language and Social Relations. Cambridge: Cambridge University Press.

Agricola, Mikael 1987 [1543-1552]. Mikael Agricolan teokset I-III. [Works of Mikael Agricola.] Porvoo: WSOY. Available at http://kaino.kotus.fi/korpus/vks/meta/ agricola/agricola_coll_rdf.xml, last accessed on February 1, 2017.

Asplund, Anneli 1994. Balladeja ja arkkiveisuja: suomalaisia kertomalauluja. [Ballads and Broadside Songs: Finnish Narrative Songs.] Helsinki: SKS.

Asplund, Anneli 1997. Murros, muutos ja mitta: metriikan, rakenteen ja sisällön välisistä suhteista suomalaisissa kansanlauluissa. [Rupture, Change and Meter: On the Relationships of Metrics, Structure and Content in Finnish Folk Songs.] Unpublished licentiate thesis. University of Helsinki.

Asplund, Anneli 2006. Runolaulusta rekilauluun: kansanlaulun murros. [From RunoSongs to Rhymed Songs: Change in Folk Singing.] In: Anneli Asplund \& Petri Hoppu \& Heikki Laitinen \& Timo Leisiö \& Hannu Saha \& Simo Westerholm (eds.) Suomen musiikin historia 8: Kansanmusiikki. [History of Finnish Music 8: Folk Music.] Helsinki: Werner Söderström, pp. 108-159.

Bastman, Eeva-Liisa 2014. Häiden topos ja morsiusmystiikan motiivit pietistisessä virsirunoudessa. [The Topic of Wedding and the Motifs of Bridal Mysticism in Pietist Hymn Poetry.] Avain, Vol. 2, pp. 46-61. Available at http://pro.tsv.fi/skts/ Avain2014_2_sisalto.pdf, last accessed on February 3, 2017.

Berntson, Martin 2016. Popular Belief and the Disruption of Religious Practices in Reformation Sweden. In: Tuomas M. S. Lehtonen \& Linda Kaljundi (eds.) Reforming Texts, Music and Church Art in the Early Modern North. Amsterdam: Amsterdam University Press, pp. 43-68.

Brown, Christopher Boyd 2005. Singing the Gospel: Lutheran Hymns and the Success of the Reformation. Cambridge, Mass: Harvard University Press.

Bure, Anders 1626. Orbis arctoi nova et accurata delineatio. Stockholm: Christoffer Reusner.

Burke, Peter 2009 [1978]. Popular Culture in Early Modern Europe. Third edition. Farnham \& Burlington: Ashgate.

DuBois, Thomas A. 2006. Lyric, Meaning, and Audience in the Oral Tradition of Northern Europe. Notre Dame, IN: University of Notre Dame Press.

Eggertsdóttir, Margrét 2006. From Reformation to Enlightenment. In: Daisy L. Neijmann (ed.) A History of Icelandic Literature. Lincoln \& London: University of Nebraska Press, pp. 174-250.

Ekgren, Jacqueline Pattison 2009. Dipod Rules: Norwegian Stev, Paired Accents and Accentual Poetry. In: Tonya Kim Dewey \& Frog (eds.) Versatility in Versification: Multidisciplinary Approaches to Metrics. New York: Peter Lang, pp. 207-222.

Finnegan, Ruth 1977. Oral Poetry: Its Nature, Significance and Social Context. Cambridge: Cambridge University Press.

Finno, Jacobus 1988 [1583]. [Hymnal]. Facsimile. In: Pentti Lempiäinen (ed.) Jaakko Finnon Virsikirja. Helsinki: SKS.

Foley, John Miles 1995. The Singer of the Tales in Performance. Bloomington and Indianapolis: Indiana University Press. 
Foley, John Miles 2002. How to Read an Oral Poem? Urbana and Chicago: University of Illinois Press.

Frog 2010. Listening to Poetry in a Dead Language: Could dróttkvætt Have Been Trochaic? RMN Newsletter, No. 1, pp. 23-28. Available at http://www.helsinki. fi/folkloristiikka/English/RMN/RMN\%20Newsletter\%20DECEMBER\%202010. pdf, last accessed on February 6, 2017.

Frog 2014. Degrees of Well-Formedness: The Formula Principle in the Analysis of Oral-Poetic Meters. RMN Newsletter, No. 8, pp. 68-70. Available at http://www. helsinki.fi/folkloristiikka/English/RMN/RMN_8_May_2014-1.pdf, last accessed on February 6, 2017.

Frog \& Stepanova, Eila 2011. Alliteration in (Balto-) Finnic Languages. In: Jonathan Roper (ed.) Alliteration in Culture. Houndmills: Palgrave Macmillan, pp. 195-218. Available at http://www.palgrave.com/us/book/9780230232648, last accessed on February 6, 2017.

Gasparov, Mikhail 1996. A History of European Versification. Oxford: Claredon Press. Gillespie, Gerald Ernest Paul 1971. German Baroque Poetry. New York: Twayne Publishers.

Grudule, Māra 2016. The Emergence of Hymns at the Crossroads of Folk and Christian Culture: An Episode in Early Modern Latvian Cultural History. In: Tuomas M. S. Lehtonen \& Linda Kaljundi (eds.) Re-forming Texts, Music, and Church Art in the Early Modern North. Amsterdam: Amsterdam University Press, pp. 217-250.

Haapanen, Toivo 1928. Suomalaiset runomittateoriat 1800-luvulla. [Finnish 19thCentury Theories on Poetic Meter.] Helsinki: SKS.

Häkkinen, Kaisa 2005. Maskun Hemmingin kieli. [The Language of Hemming of Masku.] In: Reijo Pajamo (ed.) Hymnos. Soukat sanat, maistaa suu: Hemminki Maskulaisen virsikirja 400 vuotta. [Hymnos. The Mouth Tastes Narrow Words: 400 Years of the Hymnal by Hemmingius of Masku.] Helsinki: Hymnologian ja liturgiikan seura, pp. 27-38.

Häkkinen, Kaisa (ed.) 2012. Mikael Agricolan runokirja. [The Poetry Book of Mikael Agricola.] Turku: Turun yliopisto.

Häkkinen, Kaisa 2013. Kansanrunouden aineksia vanhimmassa suomalaisessa kirjallisuudessa. [Elements of Folk Poetry in Oldest Finnish Literature.] In: Tuomas Hovi \& Kirsi Hänninen \& Merja Leppälahti \& Maria Vasenkari (eds.) Viisas matkassa, vara laukussa: näkökulmia kansanperinteen tutkimukseen. [Wise One on Travel, Allowance in the Bag: Perspectives on Folklore Studies. Turku: Turun yliopisto, pp. 56-75.

Häkkinen, Kaisa 2015. Spreading the Written Word: Mikael Agricola and the Birth of Literary Finnish. Helsinki: SKS.

Hallio, Kustaa 1936. Suomalaisen virsikirjan virret: alkuperä ja kehitys. [The Hymns of Finnish Hymnal: Origin and Development.] Helsinki: SKS. Available at http:// www.digar.ee/arhiiv/et/raamatud/42048, last accessed on February 6, 2017.

Hannikainen, Jorma \& Tuppurainen, Erkki 2016. Vernacular Gregorian Chant and Lutheran Hymn-Singing in Reformation-Era Finland. In: Tuomas M. S. Lehtonen \& Linda Kaljundi (eds.) Re-forming Texts, Music, and Church Art in the Early Modern North. Amsterdam: Amsterdam University Press, pp. 157-178. 
Hansson, Stina 2000. Från Hercules till Swea: Den litterära textens förändringar. [From Hercules till Svea: Changes of Literary Texts.] Göteborg: Göteborgs universitet. Hornby, Emma 2009. Medieval Liturgical Chant and Patristic Exegesis: Words and Music in the Second-Mode Tracts. Woodbridge: The Boydell Press.

Hymes, Dell 1981. "In vain I tried to tell you": Essays in Native American Ethnopoetics. Philadelphia: University of Pensylvania Press.

Kallio, Kati 2013. Laulamisen tapoja: Esitysareena, rekisteri ja paikallinen laji länsiinkeriläisessä kalevalamittaisessa runossa. [Ways of Singing: Performance Arena, Register and Local Genre in West-Ingrian Oral Poetry.] Diss. (PhD Thesis). Helsinki: Helsingin yliopisto. Available at http://urn.fi/URN:ISBN:978-952-10-9566-5, last accessed on February 6, 2017.

Kallio, Kati 2015a. Multimodal Register and Performance Arena in Ingrian Oral Poetry. In: Asif Agha \& Frog (eds.) Registers of Communication. Helsinki: Finnish Literature Society, pp. 322-335.

Kallio, Kati 2015b. Kalevalamitta oppineiden käytössä uuden ajan alun Suomessa. [Kalevala-Meter in the Learned Uses in Early Modern Finland.] Elore, Vol. 22, No. 1, pp. 1-30. Available at www.elore.fi/arkisto/1_15/kallio.pdf, last accessed on February 6, 2017.

Kallio, Kati 2016. Changes in the Poetics of Song during the Finnish Reformation. In: Tuomas M. S. Lehtonen \& Linda Kaljundi (eds.) Re-forming Texts, Music, and Church Art in the Early Modern North. Amsterdam: Amsterdam University Press, pp. 125-155.

Kallio, Kati \& Lehtonen, Tuomas \& Timonen, Senni \& Järvinen, Irma-Riitta \& Leskelä, Ilkka 2017. Laulut ja kirjoitukset: Suullinen ja kirjallinen kulttuuri uuden ajan alun Suomessa. [Songs and Writings: Oral and Literary Culture in Early Modern Finland.] Helsinki: SKS.

Kapchan, Deborah A. \& Turner Strong, Pauline 1999. Theorizing the Hybrid. The Journal of American Folklore, Vol. 112, No. 445, pp. 239-253. http://dx.doi. org/10.2307/541360.

Kiparsky, Paul 2006. A Modular Metrics for Folk Verse. In: B. Elan Dresher \& Nila Friedberg (eds.) Formal Approaches to Poetry. Berlin: Mouton de Gruyter, pp. 7-49.

Krohn, Julius Leopold Fredrik 1862. Suomenkielinen Runollisuus Ruotsinvallan aikana ynnä Kuvaelmia Suomalaisuuden Historiasta. [Finnish Poetry during the Swedish Regime and Some Scenes on the History of Finnish Culture.] Helsinki: Julius Krohn.

Kuismin, Anna \& Driscoll, Michael J. (eds.) 2013. White Field, Black Seeds: Nordic Literacy Practices in the Long Nineteenth Century. Helsinki: SKS.

Kurvinen, Onni 1941. Vanha virsikirja: Vuoden 1701 suomalaisen virsikirjan synty ja sisällys. [Old Hymnal: The Creation and Content of the Finnish Hymnal of 1701.] Rauma: Länsi-Suomen kirjapaino.

Kurvinen, P. J. I. 1929. Suomen virsirunouden alkuvaiheet v:een 1640. [The Beginnings of Finnish Hymn Poetry up to the Year 1640.] Helsinki: SKS.

Kuusi, Matti 1954. Sananlaskut ja puheenparret. [Proverbs and Sayings.] Helsinki: Suomalaisen Kirjallisuuden Seura. 
Kuusi, Matti 1994. Questions of Kalevala Metre: What Exactly Did Kalevala Language Signify to Its Users? In: Anna-Leena Siikala \& Sinikka Vakimo (eds.) Songs beyond the Kalevala: Transformations of Oral Poetry. Helsinki: SKS, pp. 41-55.

Kuusi, Matti 1998. Salamnius, Matthias (1640-1691). Kansallisbiografia. [National Bibliography.] Helsinki: SKS. Available at www.kansallisbiografia.fi/kb/ artikkeli/2340, last accessed on February 6, 2017.

Laitinen, Heikki 2003. Matkoja musiikkiin 1800-luvun Suomessa. [Travels to Music in 19th-Century Finland.] Tampere: Tampere University Press.

Laitinen, Heikki 2005. Barokki tunteen ja järjen dialogina: Hemminki Maskulaisen Uscovaisen sielun halu Christuxen jälken. [Baroque as a Dialogue of Emotion and Reason: 'Uscovaisen sielun halu Christuxen jälken' by Hemmingius of Masku.] In: Reijo Pajamo (ed.) Hymnos. Soukat sanat maistaa suu: Hemminki Maskulaisen virsikirja 400 vuotta. [Hymnos. Narrow Words in the Mouth: 400 Years of the Hymnal by Hemmingius of Masku.] Helsinki: Hymnologian ja liturgiikan seura, pp. 143-163.

Laitinen, Heikki 2006. Runolaulu. [Runo-Singing.] In: Anneli Asplund \& Petri Hoppu \& Heikki Laitinen \& Timo Leisiö \& Hannu Saha \& Simo Westerholm (eds.) Suomen musiikin historia 8: Kansanmusiikki. [History of Finnish Music 8: Folk Music.] Helsinki: Werner Söderström, pp. 14-79.

Laitinen, Heikki forthcoming. Karkureiten silosäkeistä. [On the Blank Verses in 'Karkurit'.] In: Riitta Pohjola-Skarp \& Sakari Katajamäki \& Ossi Kokko \& Petri Lauerma \& Juhani Niemi \& Jyrki Nummi (eds.) Karkurit: Kriittinen editio. [Runaways: Critical Edition (of a play by Aleksis Kivi).] Helsinki: SKS.

Laitinen, Lea \& Mikkola, Kati (eds.) 2013. Kynällä kyntäjät: kansan kirjallistuminen 1800-luvun Suomessa. [Ploughers with a Pen: The Development of Literacy in 19th-Century Finland.] Helsinki: SKS.

Lauerma, Petri 2004. Larin Parasken epiikan kielellisestä variaatiosta. [On the Linguistic Variation of Epic Poems by Larin Paraske.] Helsinki: SKS.

Lauerma, Petri (ed.) 2012. Rudimenta linguae Finnicae breviter delineata: suomen kielen varhaiskielioppi ja sen tausta. [An Early Grammar in Finnish and Its Background.] Helsinki: SKS.

Laurila, Vihtori 1956. Suomen rahvaan runoniekat sääty-yhteiskunnan aikana. 1. osa: Yleiset näkökohdat. [The Poets of Finnish Folk in Class Society.] Helsinki: SKS.

Lehtonen, Tuomas 2013. Spoken, Written, and Performed in Latin and Vernacular Cultures from the Middle Ages to the Early Seventeenth Century: Ramus Virens Oliuarum. In: Lars Boje Mortensen \& Tuomas M. S. Lehtonen \& Alexandra Bergholm (eds.) The Performance of Christian and Pagan Storyworlds: NonCanonical Chapters of the History of Nordic Medieval Literature. Turnhout: Brepols, pp. 109-139. DOI: 10.1484/M.MISCS-EB.1.100753.

Lehtonen, Tuomas M. S. 2016. Pious Hymns and Devil's Music: Michael Agricola (c. 15071557) and Jacobus Finno (c. 1540-1588) on Church Song and Folk Beliefs. In: Tuomas M. S. Lehtonen \& Linda Kaljundi (eds.) Re-forming Texts, Music, and Church Art in the Early Modern North. Amsterdam: Amsterdam University Press, pp. 179-216. 
Lehtonen, Tuomas M. S. \& Kallio, Kati 2017. Petrus Melartopaeuksen kirjeet ja virsisuomennokset: seremoniat, kansanusko ja runokieli 1500- ja 1600-luvun taitteessa. [The Letters and Hymn Translations of Petrus Melartopaeus: Ceremonies, Folk Beliefs and Poetic Language in Late 16th and Early 17th Century Finland.] Suomen Kirkkohistoriallisen seuran vuosikirja 2017, pp. 168-202.

Leino, Pentti 1970. Strukturaalinen alkusointu Suomessa. [Structural Alliteration in Finland.] Helsinki: SKS.

Leino, Pentti 1986. Language and Metre: Metrics and the Metrical System of Finnish. Helsinki: SKS.

Leino, Pentti 1994. The Kalevala Metre and its Development. In: Anna-Leena Siikala \& Sinikka Vakimo (eds.) Songs beyond the Kalevala: Transformations of Oral Poetry. Helsinki: SKS, pp. 56-74.

Leino, Pentti 2002 [1975]. Äidinkieli ja vieras kieli: rahvaanrunouden metriikkaa. [Mother Tongue and Foreign Language: Metrics of Literary-Influenced Folk Poetry.] In: Pentti Leino \& Liisa Tainio (eds.) Mittoja, muotoja, merkityksiä. [Dimensions, Forms, Meanings.] Helsinki: SKS, pp. 207-230.

Lilja, Eva 2003. The Staves of Alliteration and the Prominences of 'Knittel': A Contribution to the Problem of the Scandinavian Four Beat Line. Jahrbuch für Internationale Germanistik, Vol. 35, No. 1, pp. 125-138.

Lilja, Eva 2006. Svensk metrik. [Swedish Metrics.] Stockholm: Svenska Academien.

Lippus, Urve 1995. Linear Musical Thinking: A Theory of Musical Thinking and the Runic Song Tradition of Baltic-Finnish Peoples. Helsinki: University of Helsinki.

Maskulainen, Hemminki 1607. Yxi vähä suomenkielinen wirsikiria, suomencocouxis Jumalata kijttä suomenkielellä, tehty m. Jacobilda Suomalaiselda, ja muild Suomen papeilda. [Small Hymnal in the Finnish Language.] Rostock: Stephan Möllemann. Available at http://urn.fi/URN:NBN:fi-fe2015120321826, last accessed on February 3, 2017.

Melander, Toini (ed.) 1928. Suomalaista tilapäärunoutta Ruotsin vallan ajalta I. [Finnish Occasional Poetry from the Time of the Swedish Reign.] Helsinki: SKS.

Niemi, Jarkko 1998. The Nenets Songs: A Structural Analysis of Text and Melody. Tampere: University of Tampere.

Niemi, Jarkko \& Jouste, Marko 2002. Teesejä pohjoisen laulun analyysiin: tarkastelussa nenetsit ja saamelaiset. [Theses for the Analysis of Northern Singing: The Nenets and the Sami under Scrutiny.] Etnomusikologian vuosikirja, Vol. 14, pp. 161-209.

Niinimäki, Pirjo-Liisa 2007. "Saa veisata omalla pulskalla nuotillansa": Riimillisen laulun varhaisvaiheet suomalaisissa arkkiveisuissa 1643-1809. [“To Be Sung to a Tune of Its Own": The Melodies and Structure of Finnish Broadside Songs 1643-1809.] Helsinki: Suomen etnomusikologinen seura.

Nuorteva, Jussi 1997. Suomalaisten ulkomainen opinkäynti ennen Turun akatemian perustamista 1640. [Finnish Study Abroad before the Foundation of the Royal Academy of Turku in 1640.] Helsinki: Suomen Historiallinen Seura \& SKHS.

Ong, Walter J. 1982. Orality and Literacy: The Technologizing of the Word. London \& New York: Methuen. 
Opitz, Martin 2016. Raamat saksa luulekunstist. [Book about German Poetry.] Transl. by Kai Tafenau \& Maria-Kristiina Lotman. Tallinn: TLU Press.

Oras, Janika 2010. Musical Manifestations of Textual Patterning in Estonian Regilaul. Journal of Ethnology and Folkloristics, Vol. 4, No. 2, pp. 55-68. Available at https://www.jef.ee/index.php/journal/issue/view/7, last accessed on February 7, 2017.

Page, Christopher 2010. The Christian West and Its Singers: The First Thousand Years. New Haven: Yale University Press.

Petraeus, Aeschillius 1968 [1649]. Linguae Finnicae Brevis Institutio. Facsimile in 1968: Vanhat kielioppimme. [Our Old Grammars.] Helsinki: SKS.

Ramsten, Märta \& Strand, Karin \& Ternhag, Gunnar 2015. Tryckta visor: Perspektiv på skillingtryck som källmaterial. [Printed Songs: Perspectives of Chapbooks as Source Material.] Uppsala: Kungl. Gustav Adolfs akademien för svensk folkkultur.

Rapola, Martti 1934. Vanhan runon kuvastelua parissa 1500-luvun suomalaisessa virressä. [Reflects of Traditional Oral Poetry in Some 16th-Century Hymns.] Kalevalaseuran vuosikirja, Vol. 14, pp. 149-169.

Ross, Kristina 2013. Riimi sunnil sündinud elukas. [A Creature Born by Force of Rhyme.] Keel ja Kirjandus, No. 7, pp. 522-528. Available at http://www.digar.ee/arhiiv/ et/perioodika/35042, last accessed on February 7, 2017.

Ross, Kristiina 2015. Regivärsist kirikulauluni: Kuidas ja milleks kõrvutada vanu allkeeli. [From Runo-Verse to Hymns: How and Why Compare Old Sublanguages.] Keel ja Kirjandus, No. 7, pp. 457-470. Available at http://www.digar.ee/arhiiv/ et/perioodika/63571, last accessed on February 7, 2017.

Saarinen, Jukka 1988. Variaatio Arhippa ja Miihkali Perttusen epiikassa. [Variation in the Epic Poems by Arhippa and Miihkali Perttunen.] Unpublished MA thesis. University of Helsinki.

Salamnius, Matthias 1690. Ilo-laulu Jesuxesta. [The Praise Song of Jesus.] Turku: Johan Winter. Available at http://www.doria.fi/handle/10024/33317, last accessed on February 3, 2017.

Sarajas, Annamari 1956. Suomen kansanrunouden tuntemus 1500-1700-lukujen kirjallisuudessa. [Knowledge of Finnish Folklore in the 16th-18th Century Literature.] Porvoo: WSOY.

Särg, Taive 2001. Karksi regilaulude värsiehitusest esituse põhjal. [About the Verse Structure of Regilaul from Karksi on the Basis of Their Performance.] In: Tiiu Jaago \& Mari Sarv (eds.) Regilaul-keel, muusika, poeetika. [Regilaul-Language, Music, Poetics.] Tartu: Tartu Ülikooli Kirjastus, pp. 195-238.

Särg, Taive 2005. Eesti keele prosoodia ning teksti ja viisi seosed regilaulus. [Estonian Prosody and Words/Music Relationships in Estonian Old Folk Songs.] Tartu: Tartu Ülikooli Kirjastus. Available at http://dspace.ut.ee/handle/10062/551?localeattribute=en, last accessed on February 7, 2017.

Sarv, Mari 2008. Loomiseks loodud: regivärsimõõt traditsiooniprotsessis. [Created for Creation: Verse Metre of Estonian Regilaul in the Tradition Process.] Tartu: EKM Teaduskirjastus. 
Sarv, Mari 2011. Language or Culture? Possible Foreign Influences on the Estonian Regilaul Metrics. In: Mihhail Lotman \& Maria-Kristiina Lotman (eds.) Frontiers in Comparative Prosody: In Memoriam Mikhail Gasparov. Bern: Peter Lang, pp. 207-226.

Savijärvi, Ilkka 1995. Finnosta Hemminkiin - vanhimpien suomenkielisten virsikirjojen kielestä. [From Finno to Hemmingius: On the Language of the Oldest Finnish Hymnals.] In: Jaak Peebo (ed.) Läänemere rahvaste kirjakeelte ajaloost. Tartu Ülikooli eesti keele õppetooli toimetised 1. Tartu: Tartu Ülikooli Kirjastus, pp. 190-204.

Siikala, Anna-Leena 2002. Mythic Images and Shamanism: A Perspective on Kalevala Poetry. Helsinki: Finnish Academy of Sciences and Letters.

Siikala, Anna-Leena 2012. Itämerensuomalaisten mytologia. [Finnic Mythology.] Helsinki: SKS.

Suomi, Vilho 1963a. Suomenkielinen lyriikka ennen vuotta 1640. [Lyric Poetry in Finnish before the Year 1640.] In: Matti Rapola (ed.) Suomen kirjallisuus II: Ruotsin ajan kirjallisuus. Helsinki: SKS \& Otava, pp. 245-262.

Tarkka, Lotte 2013. Songs of the Border People: Genre, Reflexivity, and Performance in Karelian Oral Poetry. Helsinki: Academia Scientiarum Fennica.

Tedlock, Dennis 1983. The Spoken Word and the Work of Interpretation. Philadelphia: University of Pennsylvania Press.

VKK Flor1702 = Henricus Florinus. Wanhain Suomalaisten Tawaliset ja Suloiset, Sananlascut. [Old Finnish Homilies.] Vanhan kirjasuomen korpus. Available at http://kaino.kotus.fi/korpus/vks/meta/varia/flor1702_rdf.xml, last accessed on February 3, 2017.

VKK Hemm1605 = Maskulainen, Hemminki. Virsikirja. [Hymnal.] Vanhan kirjasuomen korpus. Available at http://kaino.kotus.fi/korpus/vks/meta/virret/hemm1605_rdf. xml, last accessed on February 3, 2017.

VKK LPet1658 = Laurentius Petri Aboicus. Ajan Tieto / Suomenmaan menoist ja vscost / erinomaisest Suomen Pispoist. [Chronicle on the Practices and Faith in Finland, Especially on Bishops.] Vanhan kirjasuomen korpus. Available at http://kaino. kotus.fi/korpus/vks/meta/lpetri/lpet1658_rdf.xml, last accessed on February 3, 2017.

VKK Menn1699 = [Jonas Mennander] Huonen-Speili. [Precepts from the Smaller Catechism.] Vanhan kirjasuomen korpus. Available at http://kaino.kotus.fi/ korpus/vks/meta/varia/menn1699_rdf.xml, last accessed on February 3, 2017.

VVE = Haapalainen, T. Ilmari \& Tuppurainen, Erkki (ed.) 2004. Vanhojen virsisävelmien editio. [Edition of Old Hymn Melodies.] Suomen vanhat virsisävelmät: Virtuaalikatedraali. [Old Hymn Tunes from Finland: Virtual Cathedral.] Helsinki: Sibelius-Akatemia, kirkkomusiikin osasto. Available at http://www2.siba.fi/cgibin/shubin/edi.cgi, last accessed on February 3, 2017.

Widenberg, Johanna 2006. Fäderneslandets antikviteter: etnoterritoriella historiebruk och integrationssträvanden $i$ den svenska statsmaktens antikvariska verksamhet ca 1600-1720. [Antiquities of the Fatherland: Ethno-Territorial Uses of History and Strivings of Integration in the Antiquarian Activities by the Swedish State ca. 1600-1720.] Uppsala: Uppsala Universitet. 
Widoff, Andreas 2013. Vad är knittel? Fyrtaktig poesi kontra rimmad prosa. [What Is Knittel? Four-Beat Poetry Versus Rhymed Prose.] Språk \& stil, Vol. 23, pp. 205-231. Available at http://www.diva-portal.org/smash/get/diva2:747826/ FULLTEXT01.pdf, last accessed on February 7, 2017.

Wexionius, Michael O. 1650. Epitome descriptionis Sueciae, Gothiae, Fenningiae, et subiectarum provinciarum. Aboae: Wald. Available at http://reader.digitalesammlungen.de/resolve/display/bsb10452846.html, last accessed on February 20, 2017.

Kati Kallio works as a postdoctoral researcher at the Finnish Literature Society in the project "Letters and songs: Registers of beliefs and expressions in the Early Modern North" of the Finnish Academy, Finland.

kati.kallio@alumni.helsinki.fi 